\title{
Formation of Microprobe Using Nickel Electrodeposition
}

\author{
Yuko SUGAI, ${ }^{\text {a }}$ Fujio ASA, ${ }^{\mathrm{b}}$ Yasuyuki OKADA, ${ }^{\text {a }}$ Tokihiko YoKOSHIMA, ${ }^{\mathrm{a}}$ \\ Toshiyuki MOMMA, ${ }^{a}$ Tetsuya OSAKA, ${ }^{\mathrm{a}, \mathrm{b} *}$ and Tadatsugu ITO ${ }^{\mathrm{b}}$
}

\begin{abstract}
aDepartment of Applied Chemistry, School of Science and Engineering; Kagami Memorial Laboratory for Materials Science and Technology, Waseda University (3-4-1 Okubo, Shinjuku-ku, Tokyo 169-8555, Japan)

${ }^{b}$ Advance Research Institute for Science and Engineering, Waseda University (3-4-1 Okubo, Shinjuku-ku, Tokyo 169-8555, Japan)
\end{abstract}

Received June 15, 1999 ; Accepted July 29, 1999

\begin{abstract}
Formation of Ni microstructure with high aspect ratio without thicker photoresist was tried by an electrodeposition method. The Ni microprobes thicker than photoresist thickness were electrodeposited on a patterned substrate using thin photoresist patterned with UV radiation. It was important for preparing Ni microprobe with high aspect ratio to keep the overpotential of patterned cathode higher, and moreover the agitation using a paddle plating cell system was so effective to form uniform microprobes.
\end{abstract}

\section{Key Words : Ni Electrodeposition, Micro-patterning, High Aspect Ratio}

\section{Introduction}

Electrodeposition combined with photolithography is applied to form micropatterned structures in the field of electronic devices and printed circuit boards. ${ }^{1,2)}$ In order to construct a high aspect ratio structure, much effort has been made using the combination of photolithography and electrodeposition. Most of those structures are formed by the fulladditive method, such as the electrodeposition of metal on the substrate which has a thick photoresist pattern as shown in Fig. 1 (a). The resist pattern is usually made with enough thickness to fill up metal by an electrodeposition. On the other hand, the microstructure with high aspect ratio can be formed by electrodeposition even using thinner photoresist where the deposited height is higher than the photoresist thickness. This method has a merit to utilize a cheap conventional UV lithography technique. As one of the examples, the mushroom bump deposited over the resist was already investigated in the printed circuit board field for the 100-200 $\mu \mathrm{m}$ size. ${ }^{3-4)}$ However up to now, there is scarcely investigation on such a microstructure of electrodeposit over the photoresist with a very small size less than $100 \mu \mathrm{m}$ size. In this work, high aspect ratio microprobes of $\mathrm{Ni}$ deposit are fabricated onto patterned substrate with larger height than the thickness of photoresist as shown in Fig. 1 (b). The morphology of the deposits is surveyed by changing the operating conditions of electrodeposition.

\section{Experimental}

Vacuum-evaporated $\mathrm{Cu} / \mathrm{Cr}$ on $\mathrm{Si}$ wafer was used as a micro-patterned substrate, on which $30 \mu m \phi$ holes were formed using about $5 \mu \mathrm{m}$ thick positive photoresist film (PMER, Tokyo Ohka Kogyo Co. Ltd.) made by a UV developing method. Ni electrodeposition was carried out using the Watt Bath. ${ }^{5)}$ The bath composition and operating conditions are shown in Table 1. A nickel plate was used as an anode. Two types of electrolyte cells were used; one was a thin layered cell where the distance between the two electrodes was 2 $\mathrm{mm}$, and the other was a paddle cell ${ }^{6}$ for purpose of agitation, where the distance between the two electrodes was $70 \mathrm{~mm}$. The structure of the deposit was observed with a Scanning Electron Microscope (SEM), and the cross sectional view of $\mathrm{Ni}$ deposit was observed with an Optical Microscope.

\section{Results and Discussion}

Figure 2 shows the schematic view of a patterned substrate used for investigation. The thickness of photoresist is about $5 \mu \mathrm{m}$. The diameter of each

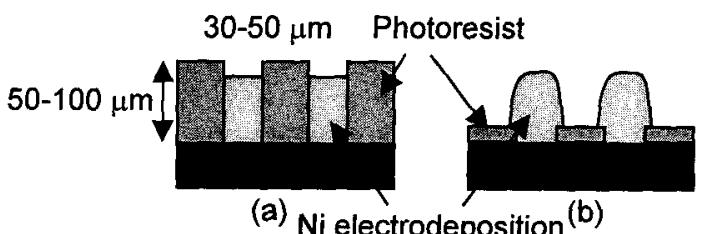

Fig. 1 Schematic models of Ni microprobe fabrication by electrodeposition. (a) conventional method, (b) this investi. gation.

Table 1 Bath composition and operating conditions for $\mathrm{Ni}$ electrodeposition.

\begin{tabular}{lc}
\hline Chemicals & Concentration $/ \mathrm{g} \mathrm{dm}^{-3}$ \\
\hline $\mathrm{H}_{3} \mathrm{BO}_{3}$ & 30 \\
$\mathrm{NiCl}_{2} \cdot 6 \mathrm{H}_{2} \mathrm{O}$ & 45 \\
$\mathrm{NiSO}_{4} \cdot 7 \mathrm{H}_{2} \mathrm{O}$ & 300 \\
\hline $\mathrm{pH}$ & $5.0($ adjusted with NaOH$)$ \\
Bath temperature & $50{ }^{\circ} \mathrm{C}$ \\
Agitation speed & $0-100 \mathrm{rpm}$ \\
Current density & $0.5-2.0 \mathrm{~A} \mathrm{~cm} \mathrm{~cm}^{-2}$ \\
\hline
\end{tabular}


pattern hole is $30 \mu \mathrm{m}$. Ni microprobes with high aspect ratio were fabricated on the patterned electrode. $\mathrm{Ni}$ was galvanostatically electrodeposited without agitation in the case of the thin layered cell. Figure 3 shows SEM images and cross sectional optical microscopic views of $\mathrm{Ni}$ microprobes on the dependence of current densities of (a) $0.5 \mathrm{~A} \mathrm{~cm}^{-2}$, (b) $1.0 \mathrm{~A} \mathrm{~cm}^{-2}$ and (c) $2.0 \mathrm{~A} \mathrm{~cm}^{-2}$ respectively, using the thin layered cell. The deposition time was (a) $20 \mathrm{~min}$., (b) $10 \mathrm{~min}$. and (c) 5 min., where the current charge passed for deposition was equal for each deposit to be compared. The $\mathrm{Ni}$ microprobes with $20 \mu \mathrm{m}$ height seem like mushrooms, which was prepared only at a current density of $1.0 \mathrm{~A} \mathrm{~cm}^{-2}$. Such a desired microstructure was not obtained at current densities of 0.5 and $2.0 \mathrm{~A} \mathrm{~cm}^{-2}$. Both of the deposits obtained at 0.5 or $2.0 \mathrm{~A} \mathrm{~cm}^{-2}$ did not have sufficient heights. The current efficiency for current density of 0.5 or $2.0 \mathrm{~A} \mathrm{~cm}^{-2}$ was considered to be lower than that of $1.0 \mathrm{~A} \mathrm{~cm}^{-2}$. The cathode potential was about (a) -0.8 , (b) -1.0 and (c) $-1.3 \mathrm{~V}$ vs. $\mathrm{Ag} / \mathrm{AgCl}$ in this thin layered cell during the deposition. The fine surface morphology of $\mathrm{Ni}$ microprobes was observed by SEM analysis. In the observation, the grain sizes of the deposits obtained at $0.5,1.0$ and $2.0 \mathrm{~A} \mathrm{~cm}^{-2}$ were confirmed to be $0.25-10$ $\mu \mathrm{m}, 0.5-3.0 \mu \mathrm{m}$ and $0.1-0.5 \mu \mathrm{m}$, respectively. The morphology of $\mathrm{Ni}$ microprobe was clearly varied with current density. Flat surface was obtained at the lower current density of $0.5 \mathrm{~A} \mathrm{~cm}^{-2}$. While at the higher current density of $2.0 \mathrm{~A} \mathrm{~cm}^{-2}$, Ni electrodeposition proceeded locally at the edges of patterned holes and flat surface was not prepared. $\mathrm{Ni}$ deposition potential was about $-0.75 \sim-0.8 \mathrm{~V}$ vs. $\mathrm{Ag} / \mathrm{AgCl}$ which was separately estimated from a cathode polarization curve in this type cell. The shape of $\mathrm{Ni}$

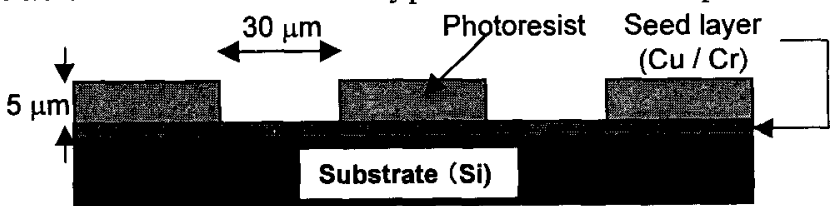

Fig. 2 Schematic model of patterned substrate for $\mathrm{Ni}$ microprobe formation.

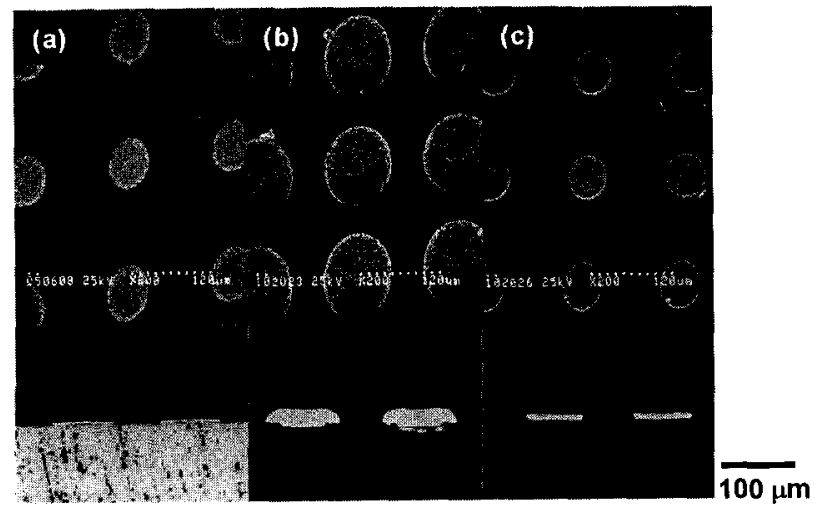

Fig. 3 SEM images and optical microscopic views of $\mathrm{Ni}$ microprobes without agitation conditions, deposition conditions : (a) current density : $0.5 \mathrm{~A} \mathrm{~cm}^{-2}$, deposition time : $20 \mathrm{~min}$, (b) $1.0 \mathrm{~A} \mathrm{~cm}-2,10 \mathrm{~min}$ and (c) $2.0 \mathrm{~A} \mathrm{~cm}^{-2}, 5$ $\min$. deposits showed that the rate determining step was diffusion of $\mathrm{Ni}$ ions at the current density of 2.0 $\mathrm{A} \mathrm{cm}^{-2}$; that was, the supply of $\mathrm{Ni}$ ions was insufficient. The effect of current efficiency and mass transport were found to have a remarkable effect in the micro-patterning. By considering the mass transportation, it appeared the possibility to prepare microprobe with high aspect ratio on the photoresist film.

Therefore, a paddle cell system was applied to enhance mass transportation. Figure 4 shows SEM images of $\mathrm{Ni}$ microprobes on the agitation dependence with current densities of (a) $1.0 \mathrm{~A} \mathrm{~cm}^{-2}$ and (b) $2.0 \mathrm{~A} \mathrm{~cm}^{-2}$. The deposition time was $10 \mathrm{~min}$ in each sample. Without agitation, the feature of the deposits was almost the same as that in Fig. 3 (b) at a current density of $1.0 \mathrm{~A} \mathrm{~cm}^{-2}$. Microprobes of $20 \mu \mathrm{m}$ thickness were prepared and the shapes became mushroom-like even without agitation. With increasing the current density to $2.0 \mathrm{~A} \mathrm{~cm}^{-2}$, the volume of deposit increased, and some large defects appeared on the side of deposits. From the results at $2.0 \mathrm{~A} \mathrm{~cm}^{-2}$, it was considerable that $\mathrm{Ni}$ ion transportation was clearly increased with using the paddle cell system instead of the thin electrolyte cell. When paddle agitation was added at $50 \mathrm{rpm}$ and $100 \mathrm{rpm}$ in the paddle cell at current densities of $1.0 \mathrm{~A} \mathrm{~cm}^{-2}$ and $2.0 \mathrm{~A} \mathrm{~cm}^{-2}$, the feature of microprobe showed no remarkable differences with various agitation speeds with current density of $1.0 \mathrm{~A} \mathrm{~cm}^{-2}$ or $2.0 \mathrm{~A} \mathrm{~cm}^{-2}$. However, the defect was found to be decreased with increasing agitation speed, and no defect was found at an agitation speed of $100 \mathrm{rpm}$. It was suggested that the accompanied $\mathrm{H}_{2}$ bubbles adsorbed or attached on the patterned surface are prevented by the paddle agitation. From these results it was clear that the agitation with the paddle plating cell system was effective to prepare uniform microstructure by electrodeposition on the patterned substrate. With this method, $\mathrm{Ni}$ microprobes with $30 \mu \mathrm{m}$ height were successfully

(a)

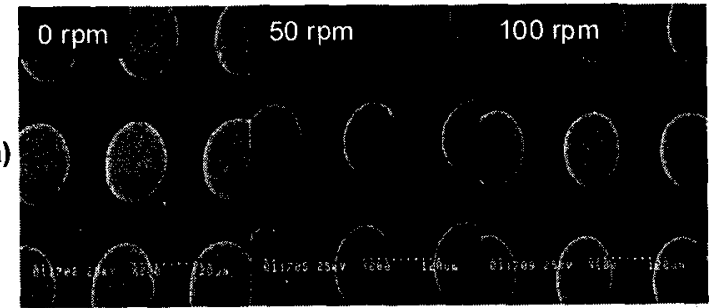

(b)

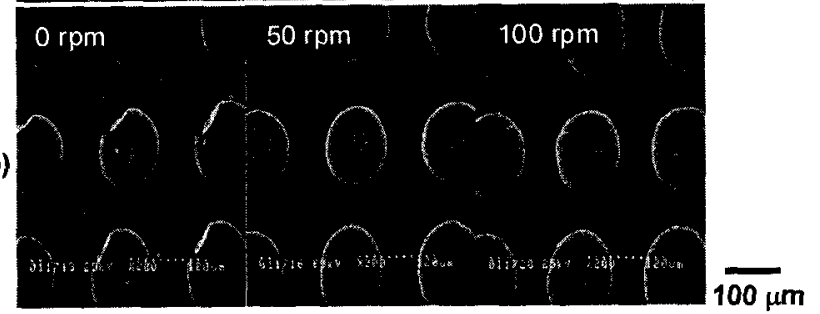

Fig. 4 SEM images for $\mathrm{Ni}$ microprobes with agitation conditions using a paddle plating cell : (a) current density : $1.0 \mathrm{~A} \mathrm{~cm}^{-2}$, deposition time : $10 \mathrm{~min}$, (b) $2.0 \mathrm{~A} \mathrm{~cm}^{-2}$, $10 \mathrm{~min}$. 
obtained even using $5 \mu \mathrm{m}$ thick photoresist.

\section{Acknowledgement}

This work was performed with financial support in part from the Grant-in-Aid for Scientific Research on Priority Areas of Electrochemistry of Ordered Interfaces from the Japan Ministry of Education, Science, Sports, and Culture No.282, and this research was supported in parf by ORIGINATIVE STUDY RESULT FOSTERING PROJECT of Japan Science and Technology Corporation.

\section{References}

1) R. E. Jones, IBM Disk Strage Technology, 3 (1980).

2) N. Baba, H. Honma, T. Osaka, and N. Oyama, Gendai Denshi Zairyou, Kodansha Scientific, p.166 (1989).

3) H. Honma and K. Hagiwara, J. Electrochem. Soc., 142, 81 (1995).

4) H. Watanabe and H. Honma, J. Electrochem. Soc., 144, 471 (1997).

5) H. Brown and B. B. Knapp, Modern Electroplating, Third Edition, (Ed. F. A. Lowenheim), John Wiley \& Sons, N.Y., Chapter 12, p.287-341 (1974).

6) E. E. Castellani, J. V. Powers, and L. T. Romankiw, $U$. S.Patent 4, 102, 756 (1978). 